\title{
The Effect Dzikr in the Development of Students Spiritual Intelligence in Suryalaya Islmaic Boarding School, Tasikmalaya
}

\author{
Basukiyatno \\ Universitas Pancasakti Tegal, Indonesia \\ \{basukiyatno@upstegal.ac.id\}
}

\begin{abstract}
This study aims to determine the effect of zikir in the development of the spiritual intelligence of students in Islamic boarding school Suryalaya Tasikmalaya. Zikir is a heart and oral worship that knows no time limit. Even Allah defends ulil albab, are those who always chant his Rab, whether standing, sitting or even lying down. With the qualitative approach of phenomenological participants, the researcher found and concluded that the zikir service at the Suryalaya Islamic Boarding School had an effect on the development of the spiritual intelligence of the students. This is through the practice of Thoriqoh Qodiriyan Naksyabandiyah (TQN) which consists of zikir jaher and zikir khofi. Jaher zikir is zikir that is pronounced loudly, and zikir khofi is instilled in the heart. Jaher recitation is carried out at least 165 times after each fardhu prayer. Jaher recitation is also carried out at any time, especially in the third of the night without being limited to the count. While the khofi zikir is carried out by the students all the time. The implementation of zikir is preceded by talqin by the murshid teacher, which is to instill the sentence of tauhid in the hearts of the students. Amaliah TQN aims to form virtuous students (al-akhlaq al-karimah) so that a complete human being is born, a human who has layers of fitriyah consciousness and indriyah consciousness. So intelligence develops from the manual-technique level in the simplest empirical world (intellectual intelligence) to the deepest tauhid level in the qoib world of fitriyah in the form of spiritual intelligence.
\end{abstract}

Keywords: Spiritual Intelligence, Dzikr

\section{Introduction}

The application of science and technology has brought many advances in human life, especially information technology. Currently internet technology has changed the pattern of life, to be very practical, efficient and effective. The system of buying and selling, trading, banking, education and other aspects of life, almost everything is internet based. The application of science and technology is not completely happy. The application of technology also leaves negative effects, such as: the warmth of the community begins to erode, personal relationships loosen up, people's lives lose their spirit. The emptiness and emptiness of life have given birth to various illnesses, both physical ailments that afflict individuals, as well as 
diseases of society. Humans are aware that material progress is not enough, and the excellence of academic intelligence cannot go alone, it takes intelligence to develop human intuition, so that they can humanize yourself completely.

Nataatmadja (2002: 38-39) demonstrates various patterns of intelligent, slanderous, spirit and ideological construction, both at the scientific paradigm level, the level of biophysical insight. mind) the West that is separated from the issue of value. The logical thinking approach, linear thinking, relying on intellectual intelligence, creates a lot of personal wholeness chaos. Life cannot be separated from meaning, values that are very decisive in making every decision. A rational approach is not equipped with tools to learn something that cannot be measured objectively In line with this, the logical thinking approach requires people to abandon intuition, perceptions and sounds of the heart, as well as things that are less rational and less objective. The fact that the issue of harmony in life in society has triggered the emergence of various spiritual movements[1].

One of these spirituality movements is the zikir movement. The Suryalaya Islamic Boarding School teaches dhikr packaged in a practice called Thoriqoh qodiriyah Nasyanbandiyah (TQN). All students of the Suryalaya Islamic Boarding School are obliged to carry out TQN. One of them is the group of students who are victims of napsa, and groups of stressed people This is the victim of family chaos and disharmony. They become students because they want to recover from drug addiction and relieve stress. They do not live enough in their wealth and knowledge intellectually. They need an understanding of their wholeness, intellectual, emotional and spiritual intelligence. This research wants to know whether the influence of zikir taught by Pesantren Suryalaya on the development of spiritual intelligence?

\section{Method}

This study applies a qualitative method with a phenomenological approach. Bertens (1987: 3 ) gives the meaning that phenomenology is the science of phenomena or what is visible. This understanding is in line with Moleong (1990), that research in a phenomenological view means understanding events in relation to people in certain situations, so that phenomenologists emphasize the subjective aspects of people's behavior and interpretations of their self-understanding. Understanding certain situations requires research that is natural or natural as it is, without being manipulated, regulated by experiments or tests, this approach is known as the naturalistic method (Nasution, 1988).

\section{Results and Discussion}

\subsection{State of Santri}

The Suryalaya Islamic boarding school has thousands of santri consisting of several groups. Among them are students who are specialized in boarding, boarding and school / college students, inabah students. These inabah students have special characteristics. The children who are mentored, initially are children who are experiencing disorders , maybe drug disorders, or other psychiatric disorders. They are difficult to bring into inabah, so it must be with certain seductions. In general, they are seduced and persuaded that they will be invited to take a tour, from a tourist attraction and then diverted to the Suryalaya Islamic Boarding School. When they meet Pangersa Abah they will be punished and their disease will be 
discovered, so that the appropriate Inabah can be appointed. There are also those who come directly to Inabah, then the Inabah supervisor reports to Pangersa Abah. This tolerance is given because it is very difficult to bring prospective foster children to be very difficult, they are children who are sick / suffering from disorders in the form of drug addiction, and children with stress disorders. acceptance, the supervisor conducts interviews with prospective children and their parents / guardians, so that the background of family life, parental treatment, and social conditions can be found. Based on the data from the interview, the children of coaches will receive appropriate treatment according to their conditions. All students are required to carry out zikir. The children of Bina Inabah have the obligation of dhikr and bathing at night and praying sunnah.

\subsection{Dhikr}

The Suryalaya Islamic boarding school has the main teaching of zikir, which is packaged in the Thoriqoh Qodiriyah Nasyabandiyah (TQN). Zikir is an effort to gain full awareness of the greatness and power of Allah SWT., Full self-awareness of its existence as a creature of Allah Almighty, and the struggle for mahabbah to- All students are obliged to practice dhikr. Inabah bina inabah children also have additional night baths and sunnah prayers.

The zikir at the TQN Pesantren Suryalaya has specific specifications, namely zikr jaher and zikir khofi. Ginger dhikr is one that is said aloud with a head movement like a person shaking his head. Shaking the head is actually a movement of the head from facing the center of the self in the stomach, then fully pulled upwards, the head is nodded to the right side of the chest, then pulled up again and then nodded in the left chest, precisely at the center of the heart. This movement serves to strengthen the dhikr that is pronounced and at the same time believed to close the doors of satan's entrance from the face, right side, and left side. So dhikr jaher becomes a steady activity, and it is both interesting and at the same time removing sins. Ginger remembrance is carried out after every prayer. , at least 165 times, besides that also in one third of the night, the time of kiyamul lail as much as possible.

Khofi dhikr is dhikr which is dhikr that is done in the heart, carried out after every dhikr of Jaher, and throughout his lifetime. Dhikr is an attempt to gain full awareness of the greatness and power of Allah SWT., Full self-awareness of his existence as a creature of Allah Almighty, and the struggle for mahabbah to Him. If zikir jaher is more of a strong inculcation of the word of God Allah, then khofi dhikr is a fortress for everyone from all immoral practices, because of his awareness of the existence of Allah who is very close to him. That is what they believe to be the pinnacle of self-intelligence, namely closeness, love for Allah completely. Almost everyone who is visiting the Suryalaya Islamic Boarding School for the first time will be amazed when after praying he witnesses the dhikr loudly and shaking his head. Likewise the atmosphere in a third of the night where the atmosphere is already full of people reciting dhikr. That is how the daily activities are practiced at the Suryalaya Islamic Boarding School. People worship diligently from one third of the night to dawn followed by the isrof prayer and duha prayer. But what the students mainly do is dhikr.

\subsection{Talqin Zikir}

Talqin is bai'at from murshid so that children say the sentence of dhikr. The meaning of talqin in its essence is to awaken one's qudsi spirit, therefore not just anyone can do it. Students who are being trained will generally cry bitterly, regretting past sins. They will also begin to feel that life and death belong only to Allah, and only Allah can heal and forgive sins. 
After crying his heart out, as an emotional release he will feel relieved to have been freed / reduced from the shackles of the past. Children / students have just started coaching at the Suryalaya Islamic Boarding School by following talqin. For example, people who have just entered something, namely just planting or have just planted, or have just entered the gate to open a house. by practicing dhikr in a serious and continuous manner.

\subsection{Discussion}

\section{a) The Meaning of Dhikr in Life}

Allah affirms that only with dhikr can the heart be calm (the Koran). Between the words of Allah in Surah Al-Ahzab, verses 41-42, "O you who believe, do dhikr (by mentioning the name) of Allah, as much as possible. And pray to Him in the morning and evening. "Praying

which literally means we always chant the name of Allah and live it in a sublime way. With dhikr, anxiety, emotional anxiety and anger can disappear by itself. Eliminate worries in the relationship between oneself and Allah. People who are negligent, of course, will be haunted by worries between themselves and Allah, which cannot be eliminated except with dhikr (Yazid bin Abdul Qadir Jawas, 2003). Furthermore, Yazid bin Abdul Qadir Jawas (2003) argues that if it is more understood that in the heart there is a gap which cannot be blocked at all except with dhikr. If dhikr is a motto of the heart and it also reminds us of the path that should be taken, then this is dzikir called dzikir that can cover the gap so that people become rich not because of wealth, respected not because of descent, respected not because of power. But if he neglects to make dhikr to Allah then his situation will be the opposite, he is poor even though he has a lot of wealth, is despicable even though he holds power and is not seen even though his family is well established. There is a lot to remember (recite dhikr) to Allah either in the morning, in the evening, and at night or after performing the fardhu prayer and sunnah prayer. Recitation can be done by sitting, lying down or standing, recited silently or orally (Alquran Surat Ali imron 191).

Spiritual intelligence at the Suryalaya Islamic Boarding School is identified by several main elements as follows: The basic elements are: inspiration, voice of heart, god spot, life of divinity. The format model is: combining units / elements, placing oneself in a broader and richer context, blending sensory and spiritual functions in morality and ethical values, actualizing love for Allah. The level of surrender to Allah, and the level of their addiction to drugs. Seriousness in dhikr is very helpful in developing their awareness that Allah is in control of everything, and opens up all possibilities for their servants. That is actually a consciousness which is the essence of spiritual intelligence. This awareness has provided self to solve the problems it faces intelligently in the spiritual dimension, a dimension of the most essential human life.

The majority of human beings are dominated by economic problems. An increasingly difficult economic life makes competition sharp, and tends to justify any means. Economic life is increasingly limited by available resources, with the number of people who are multiplying, making life harder, competition is getting sharper, kinship easily fades, honesty fades, and a number of other moral degenerations.

A hard life makes the life of the majority of people restless, anxious, prejudiced, angry, envious, and the like. Life is focused on the stillness of the world, rarely people still have a desire for the life of the hereafter. Dhikr is learning to fully devote oneself to God, while worship Praying to achieve the servitude of God and fellow human beings. By establishing a relationship with God and fellow human beings, the practice of the Caliphate on this earth is 
actually completed. In this context, the Suryalaya Islamic Boarding School has the view that a human being is intellectually, emotionally and spiritually intelligent. They place and place spiritual intelligence in the highest position, because the position of man is not only controlled by his intellect, emotion but by his spirituality. This is based on the most complete rule of spiritual life with a regular herarchi structure.

\section{b) Spiritual Intelligence Development}

The competition for the domination of reason and heart in human culture is always in flux (Shaffer, A. Jerome 1968, Achmad Sanusi, 1999, Tafsir, 1999). Since Thales put forward his philosophical thoughts, the work of the mind has begun to surprise humans. Philosophers study the power of reason for human progress With the symbol of progress in the form of 'material', reason has brought about very rapid changes. This progress tends to negate the soul (religion), even religion is considered to only hinder progress.

The turning point of this peak of thinking arises when reason is felt to have opposed humans so that in turn humans will oppose reason (Tafsir, 1999: 4). The competition between mind and soul reaches its peak, that matter (reason) does not exist, there is only a soul (mind), on the contrary that the soul does not exist, there is only matter. Thought is strengthened, completed and even annulled by the results of thought, this is one of the works reason, so that the competition for thought can dynamize progress. Kant's philosophy has arrived, which has led to the peak of the rationalist view of human nature, so that the mind and soul (faith) are in their respective positions and run in harmony (Tafsir, 1999: 4).

History will always rotate, which also happens in the field of thought and civilization (AlQuran; Capra, 2000; Huntington, 2001; Shaffer, 1968; Achmad Sanusi, 1999). The evolutionary wave of thought has led to a fundamental revision of the belief that the scientific method is the only valid approach to knowledge. The direction and style of thinking of positivism-empirical, with the criteria of logical-rational-uniform, are considered to give rise to habits, complexity, turmoil, crises, shifting of values and chaos (Achmad Sanusi, 1999: 2).

The value system that sensory perception is the only source of knowledge and truth has shifted and acknowledges that knowledge can be obtained through inner experience (Fritjof Capra, 2000: 17-18; Hidayat Nataatmadja, 2001: xxv; Amir An-Najar, 2001: 100) . The paradigm of learning has shifted, that there are many sources and ways to gain knowledge (Davies, 2001; Amin Syakur, 2001). The ability of logic in developing an independent, critical, logical, rational and objective human thinking approach has brought progress and the development of science and technology very rapidly. The thinking approach that puts forward logic, identifies the object of study is limited to physical and organic facts that actually exist, and is inherently attached to the object itself, so that significant, relevant, orderly, autonomous and definite characteristics are obtained. That's the concept of intellectual intelligence[2].

Zikir Suryalaya Islamic boarding school teaches and fosters students (ikhwan) to love and seek the pleasure of Allah in their lives. This process is achieved through the zikr persistence of each student. The results vary, there are students who quickly reach wusul, mortal, and succeed in reaching God. In principle, every human being has a divine point, a god spot, things that make a person very close to their god, or vice versa. Murshid teachers demand their students to come to their god immediately. One of the efforts he took was a prayer that they always recited, divine anta maksudi, waridho kal madlubi, a'tini mahabbataka, wamakrifataka. O God, it is you who I mean, and it is Your blessing that I am looking for, give me the ability to be able to love You and knowingly for You. That is the process of placing oneself in a broader and richer context, the combination of sensory and spiritual functions in morality and 
ethical values, the actualization of love for Allah, so that it can solve the main problems of life effectively. So the students strive hard, with disciplined practice to attain spiritual intelligence.

\section{Conclussion}

Dhkir is a form of worship that Allah commands every Muslim. Dhkir can be carried out in the morning, afternoon, evening and night, in a standing, sitting or lying position. Zikir Suryalaya Islamic Boarding School teaches and fosters students to love and seek Allah's pleasure in their lives. Seriousness in dhikr is very helpful in developing self-awareness that Allah is in control of everything, and opens all possibilities for his servants. That is actually a consciousness which is the essence of spiritual intelligence. This awareness has equipped itself to solve the problems it faces intelligently in the spiritual dimension, one dimension of the most essential human life. In a life that is increasingly difficult, hard, fierce competition colored with various forms of lies and other crimes, let us multiply the dhikr. Dhikr calling, and remembering the Lord Allah, wholeheartedly make us as if we have been in his grasp for salvation and happiness. The totality of living with Allah, That is the essence of spiritual intelligence. Armed with peace, safety and happiness Amen.

\section{References}

[1] S. Triswidiastuty and A. Rusdi, "PENURUNAN SIMPTOM DEPRESI PADA PASIEN BIPOLAR MENGGUNAKAN TERAPI DZIKIR : INTERVENSI KLINIS," vol. 3, no. 1, pp. 43-48, 2019.

[2] O. D. Kumala, Y. Kusprayogi, and F. Nashori, "Efektivitas Pelatihan Dzikir dalam Meningkatkan Ketenangan Jiwa pada Lansia Penderita Hipertensi,” vol. 4, pp. 55-66, 2017.

[3] Adam, Muchtar Adam \& Fadlullah Muh.Said (2009). Ma'rifatullah-Membangun Kecerdasan Spiritual, Intelektual, Emosional, Sosial dan Akhlak Karimah, Bandung : Makrifat Publisher, Cetakan Keempat.

[4] Amin Syakur (2001). Tasawuf dan Aktivitas Ekonomi dI Jawa. Studi Kasus Thorekot Qodiriyah Naqsyabandiyah di Jawa.Jakarta : Depag.

[5] Amir An-Najar, (2001). Ilmu Jiwa Dalam Tasawwuf.Terjemah: Hasan Abrori. Jakarta : Pustaka Azzam.

[6] Bagus, Lorens (2000). Kamus Filsafat. Jakarta: PT. Gramedia.

[7] Bertens, K, (1987), Fenomenologi Eksistensial, Jakarta: PT. Gramedia.

[8] Busthomi, Yazid. (2018). Macam-macam Kecerdasan Spiriyual dalam Konsep Pendidikan Luqman Al-Hakim. Jurnal Athttp://ejorunal.kopertais4.or.id/mataraman/index.php/tahdzib/article/view/3350 diakses pada 07 Oktober 2020.

[9] Dahlan, Djawad M (2002) "Suatu Upaya Memahami Kecerdasan Spiritual (Kecerdasan Ilmu Laduni), makalahseminar. Bandung: PPs UPI.

[10] Drijarkoro SJ. (1978). Filsafat Manusia . Yogyakarta: Kanisius.

[11] Education encyclopedia. (2017). Intelligence - Multiple Intelligences : Thery, Gardner, assessment, and based: State University.

http://education.stateuniversity.com/pages/2102/Intelligence-MULTIPLEINTELLIGENCES.html\#ixzz4hvjiIE9J. 
[12] Hernowo dan Deden Ridwan, (2002).Aa Gym dan Fenomena Daarut Tauhid. Memperbaiki Diri Lewat Managemen Qolbu. Bandung : Mizan.

[13] Http://eprints.ubhara.ac.id/417/ Junrla Pengaruh Kecerdasan Kineja, Emosional, Dan Spiritual Terhadap Kinerja Guru SMP Negeri di Surabaya diakses tanggal 22 September 2020 Pukul 22.20 WIB.

[14] Inayat Khan. (2000). Dimensi Spiritual Psikologi . Penerjemah Andi Haryadi. Bandung: Pustaka Hidayah.

[15] Marzuki Wahid, (ed) (1999) Pesantren Masa Depan Bandung: Pustaka Indah.

[16] Moleong, Lexy J. (1990).Metodologi Penelitian Kualitatif. Bandung: PT Remaja Rosda Karya.

[17] Nasution, S. (1988).Metodologi Penelitian Naturalistik Kualitatif.Bandung: Tarsito.

[17] Nataatmadja, Hidayat. (2001). Inteligensi Spiritual, Jakarta: Perenial Press.

[18] Othman, Ali Issa (1981). Manusia Menurut al Qozali . Bandung: Pustaka Salman ITB.

[19] Sinetar, Marsha, (2001). Spiritual Intellegence alih bahasa, Soesanto Boedidarmo.Jakarta; PT Gramedia.

[20] Slamet Iman Santosa (1981) Pembinaan Watak, Tugas Utama Pendidikan. Jakarta: UI Press.

[21] Sri, lanawati.(1999). Hubungan antara Emotional Intelligence dan Intelektual Question dengan Prestasi Belajar Mahasiswa SMU. Tesis Master : Fakultas Psikologi Universitas Indonesia.

[22] Tafsir, Ahmad. (2000). Tilsafat Umum: Akal dan Hati Sejak Thales sampai Capra. Bandung: Rosda Karya.

[23] Toto Tasmara, (2001). Kecerdasan Ruhaniah (Transcendental Intelligence).Jakarta: Gema Insani.

[24] Yazid bin Abdul Qadir Jawas (2003). Doa \& Wirid-Mengobati Guna-guna dan Sihir Harmathilda H. Soleh Do'a dan Zikir Dalam Meningkatkan Kecerdasan Emosi ... 39 ISSN: 2502-728X Menurut Al-Qur'an dan As-Sunnah, Bogor: Pustaka Imam AsySyafieci, Cetakan Ketiga.

[25] Zohar, Danah dan Ian Marshall (2000).Spiritual Intelligence, The Ultimate Intellegence. London: Bloomsbury Publishing. 